E.A. Sokolova, V. Linhartova, V.V. Sergeev

\title{
ECONOMIC FEASIBILITY OF GEOTHERMAL HEAT PUMPS FOR HOUSING ESTATE HEATING
}

\author{
Е.А. Соколова, В. Линхартова, В.В. Сергеев \\ ЭКОНОМИЧЕСКАЯ ЦЕЛЕСООБРАЗНОСТЬ \\ ПРИМЕНЕНИЯ ГЕОТЕРМАЛЬНЫХ ТЕПЛОВЫХ НАСОСОВ \\ ДЛЯ ТЕПЛОСНАБЖЕНИЯ ЖИЛЫХ КОМПЛЕКСОВ
}

\begin{abstract}
Energy conservation is one of the most important strategic initiatives of the «Energy Strategy of Russia until 2030», approved by the order of the Russian Federation government No. 1715-r of November 13, 2009, as without its large-scale implementation the development of the Russian economy will be limited to energy and environmental factors. Therefore, it is necessary to use the international experience of energy efficient technologies, such as heat pump installations in the heat supply systems of residential buildings and the development of integrated energy-saving measures, to create and secure stable, highly efficient, uninterruptible power supply in Russia. The article, written by V. Linhartova, E. Sokolova and V. Sergeev, is devoted to the presented problem. It considers the existing district heating system in the Czech Republic and the Russian Federation, exemplified by two major cities - St. Petersburg and Prague. The authors identified similar and different features in climate, geography, political and economic situation, analyzed the economic feasibility and technological possibilities of transferring the residential complex, both existing and new, to their own power supply. In addition, the authors calculated the economic benefit from the use of low-grade heat in the heating system (heating, ventilation and hot water supply) of the residential complex through the use of geothermal heat pump systems. The article results into the conclusion that its is inappropriate to use low-grade heat recovery systems due to lower prices of the fuel source, and consequently the price of the consumed heat load. However, the authors, referring to the inevitable exhaustion of natural resources, are confident about the prospects of their research and are ready to continue investigations in this area.

GEOTHERMAL HEAT PUMP; INDICATORS OF ECONOMIC EVALUATION; HEATING SYSTEMS; DISTRICT HEATING; ECONOMIC ATTRACTIVENESS.
\end{abstract}

Энергосбережение является одной из важнейших стратегических инициатив «Энергетической стратегия России на период до 2030 года», утвержденной распоряжением правительства РФ № 1715-р от 13 ноября 2009 года, поскольку без его масштабной реализации развитие экономики России будет ограничено энергетическими и экологическими факторами. Поэтому необходимо, опираясь на мировой опыт внедрения энергоэффективных технологий, таких как включение теплонасосных установок в состав систем теплоснабжения жилых зданий и развитие комплексных мер по энергосбережению, создавать и закреплять устойчивое, высокоразвитое, бесперебойное энергоснабжения в России. Статья В. Линхартовой, Е.А. Соколовой и В.В. Сергеева посвящена представленной задаче. В ней были рассмотрены существующие системы централизованного теплоснабжения в Чешской Республике и Российской Федерации, на примере двух крупных городов: Санкт-Петербурга и Праги, выявлены их схожие и различные черты в виду климата, географии, политической и экономической ситуации. Авторами были проанализированы экономическая целесообразность и техническая возможность перевода жилого комплекса, как существующего, так и нового, на собственное энергообеспечение. Помимо этого подсчитан экономический эффект от использования низкопотенциальной теплоты в системе теплоснабжения (на отопление, вентиляцию и горячее водоснабжение) жилого комплекса на основе применения геотермальных теплонасосных установок. После рассмотрения всех возможных вариантов подключения абонента к системе теплоснабжение, был сделан вывод о нецелесообразности использования систем утилизации низкопотенциального тепла в виду низких цен на исходное топливо, а соответственно и цен за потребленную тепловую нагрузку. Но авторы, ссылаясь, на неизбежность исчерпания природных ресурсов уверены в перспективности своих исследованиях и готовы продолжать научные изыскания в данной области.

ГЕОТЕРМАЛЬНЫЙ ТЕПЛОВОЙ НАСОС; ПОКАЗАТЕЛИ ЭКОНОМИЧЕСКОЙ ОЦЕНКИ; СИСТЕМА ТЕПЛОСНАБЖЕНИЯ; ЦЕНТРАЛИЗОВАННОЕ ЭНЕРГОСНАБЖЕНИЕ; ЭКОНОМИЧЕСКАЯ ПРИВЛЕКАТЕЛЬНОСТЬ. 
Heating and hot water preparation together with ventilation air preheating are basic energy consumers in dwellings. During their history, heating systems have undergone long development. Nowadays the main issue is how to use the primary sources as efficiently as possible in connection with environmental aspects and sustainable development. While using traditional primary sources, the population should consider that they are not something taken for granted, and they are scarce. It is considered, that the compensatory solutions with high technical and economic efficiency must be available.

The utilization of environmental and energy efficiency renewable sources will improve environmental conditions in cities, where traditional primary energy sources are burned and the air is polluted. According to Russian Prosecutor General's office, $53 \%$ of the urban population lives in areas with high or very high level of air pollution [1]. The Air Pollution Index (API) in Saint Petersburg is a little less than 7, which means the city is on the boundary between high and extremely high air pollution. There is also a statement that industrial enterprises often do not install purifying equipment because the fine rate for exceeding emission limits is very low. For industrial enterprises it is more economical to pay the fine every year than modernize the purifying equipment. Its modernization is extremely slow. Poor air conditions can increase the number of asthma cases, worsen the situation with cardiovascular diseases and what is more - to lead to the rise in lung and bronchial diseases. Basically, it adversely affects children's health, weakens the immune system and leads to chronic respiratory and other diseases.

St. Petersburg and Prague are two large and beautiful, but quite different cities. Their location, weather, political system, social orientation - are not similar at all. Undoubtedly, all of these aspects affect different fields of people's private life, which dictates its own preferences in choosing living conditions.

Truly, innovations in the Russian Federation (RF) seem to be simple and everyday technologies for the Czech Republic (CR). The first reason is the delayed development of Russia. Since the fall of the Soviet Union until 2003, the country was in the doldrums, the industry stopped, many companies went bankrupt and many factories were closed. The equipment was morally and physically outdated, fundamentally new technologies were not offered, highly qualified personnel were not trained, and investments in the energy sector were insignificant.

In 2003, there was a rise in the electricity output, which was due to the increased demand. However, this resulted into new problems: a lack of generating capacity and their inefficient use, the complexity of the transmission to the consumer in connection with weak mains. According to the European Bank, radical restructuring of the industry with the purchase of new equipment for all power plants and the attraction of skilled workers were urgently needed for the Russian energy sector.

For more than 60 years CR has widely used heat pumps not only in individual heating circuits, but also centralized ones. Development and improvement of heat pump systems are most urgent issues of modern industry. The main areas of their application are different heating systems and efficiency improvement in industrial processes [2]. In all these cases, with their application people solve the problem of thermal resources energy saving. Heat pumps, placed on the combined heat and power plants (CHP) or large combustion plants and sewage treatment plants, show an excellent example of environmentally friendly, economical and technically expedient devices [3].

Another serious problem of the Russian industry is its high power consumption. The energy cost of the gross domestic product several times exceeds the global average. According to the statistics, a decline in the domestic demand for electricity will decrease with the introduction of less energy-intensive technologies and the modernization of fuel and energy complex as a whole.

This may be achieved by:

- Introduction of technologies with low payback period of 1.5 years;

- Creating the systems of economic incentives for energy saving (extra-budgetary funds, demonstration areas, etc.);

- Training targeted energy efficiency programs at the federal, regional and municipal levels aimed at the use of alternative energy sources (development of independent power supply, development of control systems for energy consumption, etc.) [4].

According to the World Energy Council (WEC) in 2020, all developed countries will receive $75 \%$ of the thermal energy in the form of heating and hot domestic water preparation from geothermal stations. This prediction is confirmed successfully. Nowadays, the world has about 
20 million of heat pumps with various capacities. Therefore, for example, in Sweden, which is the undisputed leader in a number of the used heat pumps, the total amount of heat generated by the heat pump is more than $50 \%$. Only in Stockholm this figure is close to $15 \%$. However, in RF heat pumps did not become popular because of a lack of technically implemented and economically justified schemes for the utilization of low-grade heat from large sources [5].

The major difference between RF and CR is the approach to energy saving and efficiency. In Prague, central heating plants are modernized gradually. The energetic concept of the European Union EU has a goal to use renewable energy sources instead of the usual ones, to reduce air pollution, prevent different diseases, etc. The CHPs shall meet these regulations. If they do not modernize their equipment and reduce the heat loses, the price of heat will become too high and consumers will disconnect from the district heating systems.

European regulations on the overall efficiency of buildings force Member States of the European Union to take measures in order to reduce energy consumption and carbon dioxide emissions. The decision on energy conservation (EnEV) marked the transformation of the national law in 2002. The first construction and civil engineering heating requirements for buildings began to be considered as a single complex. The maximum state support was provided to the systems, using energy from the environment, as well as installations with a high degree of heat recovery.

However, in CR the price of heat is very different for each city (Tab. 1). The exchange rate in calculation is $27 \mathrm{CZK}$ for 1 EURO. As a result, some consumers changed the central heating system to the local one; however, many people continue to use it.

Table 1

Prices of heat in different cities in Czech Republic [6]

\begin{tabular}{|l|c|l|}
\hline \multicolumn{1}{|c|}{ CITY } & $\begin{array}{c}\text { PRICE OF HEAT } \\
\text { Euro/GJ, 2014 }\end{array}$ & \multicolumn{1}{c|}{ MAIN FUEL } \\
\hline Pardubice & 15,9 & brown coal \\
\hline Pilsen & 18,2 & brown coal \\
\hline Ostrava & 19,8 & black coal \\
\hline Prague & 21,3 & natural gas and black coal \\
\hline Olomouc & 22,2 & black and brown coal \\
\hline Brno & 24,7 & natural gas \\
\hline
\end{tabular}

In RF, there are a lot of debates about the necessity of renewable energy sector development, but practically there are no actions. Only nowadays, the country tries to transit to the renewable energy sources (RES) due to the systemic approach to energy efficiency. It includes measures to improve the efficiency of fuel and energy resources, the establishment of the regulatory framework and information technology, also all sorts of methods and criteria for evaluating the effectiveness of energy saving, energy-saving measures both in industry and in housing and communal services, energy audits and new energy technologies.

According to the statistics, the centralized heating system provides heat for about $75 \%$ of all consumers in RF. However, about $35 \%$ of the required heat is provided by heat supply systems, systems in which heat sources combine heat and power (CHP) of various capacities. District heating systems have great importance for the organization of rational energy in the country, because they are the most advanced technological means of electric and thermal energy and one of the main ways to reduce fuel consumption for these types of energy. In total, a large cogeneration system produces approximately $6.28 \mathrm{PJ} /$ year, of which $47.5 \%$ for solid fuels, $40.7 \%$ for gas and $11.8 \%$ for liquid fuels [6].

Power and heating plants in CR produced $66.14 \%$ of the total heat production. There were 1.48 million households where the heat energy from the district heating system was delivered. In order to produce the energy in central heating plants $68 \%$ of the primary energy is originated in $\mathrm{CR}$, the rest of the energy needs to be bought. The install heat power input on boilers in CHPs was $46653 \mathrm{MW}$ in 2012. The install electricity power input on generators in CHPs was 15607 MW in 2012 [7].

The original district heating piping systems in CR distributed the heat by hot steam. The replacement of the steam piping by the hot water piping system started approximately in the year of 2000. The modernization takes place gradually from bigger cities to smaller ones. For example, in 2014 a $18.5 \mathrm{~km}$ of old piping was replaced [8].

In RF, on the contrary, due to the obsolescence of domestic heating systems (Tab. 2), rough operation, long inefficient heat supply and regulation, the passage of the peak load, the number of combined heat and power CHP is reduced. 
Table 2 low demand for heat pumps. Earlier, the

Centralized CHP in St. Petersburg [9]

\begin{tabular}{|c|c|c|c|c|}
\hline $\begin{array}{c}\text { Station } \\
\text { number }\end{array}$ & $\begin{array}{c}\text { Date } \\
\text { of input }\end{array}$ & $\begin{array}{c}\text { The type and } \\
\text { brand of } \\
\text { equipment }\end{array}$ & $\begin{array}{c}\text { Year of } \\
\text { achieving } \\
\text { economic } \\
\text { life }\end{array}$ & $\begin{array}{c}\text { Year } \\
\text { achieving } \\
\text { individual } \\
\text { resources } \\
\text { based on } \\
\text { extension }\end{array}$ \\
\hline \multicolumn{5}{|c|}{ Turbines } \\
\hline 1 & 31.12 .1929 & «P-2/12/1.0» & 1964 & \\
\hline \multicolumn{5}{|c|}{ Steam boilers } \\
\hline 1 & 31.12 .1912 & «B-W» & 1942 & 2015 \\
\hline 2 & 31.12 .1912 & «B-W» & 1942 & 2013 \\
\hline 3 & 31.12 .1914 & «B-W» & 1944 & 2016 \\
\hline 4 & 31.12 .1912 & «B-W» & 1942 & 2016 \\
\hline 5 & 31.12 .1916 & «B-W» & 1946 & 2016 \\
\hline 6 & 31.12 .1916 & «B-W» & 1946 & 2014 \\
\hline
\end{tabular}

Obviously, that introduction of new technologies at facilities with outdated equipment, which has repeatedly been subjected to the repair, will be accompanied by the significant capital and operating costs, as well as the inability to ensure the reliable operation of the heat pump system in the case of failure of the obsolete equipment.

Generally, there are no efficiency demands for heat pumps in RF, though it could be a great breakthrough to use them on the existing CHP and hereby to renew the entire energy system. No national standards, which require minimal coefficient of performance (COP) or seasonal performance factor (SPF), mandatory certification of design and installation organizations, whose activities are connected with heat pumps, minor fines for extra emissions; finally there are no government grants for the transition from liquid, gaseous fuels and direct electric heating to the use of heat pumps, which stimulates many Czech companies to develop these technologies.

The next reason for differences is the cost of primary energy. Everybody knows that RF has the largest gas reserves. The price for natural gas from the district heating network is 0.132 Euros. $\mathrm{m}^{-3}$ for St. Petersburg; in Prague, to compare, this figure is about 0.570 Euros. $^{-3}$ (2014). Probably, the relatively low cost and wide distribution of gaseous fuels resulted in a scientist Udrits proved that at a low cost of fuel the cost of electricity reduces, and in such circumstances it is advantageous to carry out a direct electric heating. European countries have to buy fossil fuels abroad, which leads to the search for alternative sources and development of new technologies.

The heat pump can be used for heating, airconditioning (ventilation) and hot domestic water preparation. As a source of low-grade heat, engineers use air, water, soil heat, waste heat, and the heat from solar collectors. The main condition is to heat working fluid with their help in order to get the desired temperature from the condenser, the level the temperature for RF and $\mathrm{CR}$ is different. In the first case, according to the standards, a temperature range of heat networks is $95 / 70{ }^{\circ} \mathrm{C}$. In the second is $75 / 55{ }^{\circ} \mathrm{C}$. That means that the sufficient temperature of $75^{\circ} \mathrm{C}$ for the Czech heating system is suitable only for the underfloor heating system or air conditioning in Russia.

Considering technical conditions, efficiency and economic aspects in RF and CR, the most suitable is to consider heat from geothermal vertical loops as a renewable energy source. The heat from the ground will be a primary energy source for a brine-water heat pump. The calculation is handled with the replacement of a traditional non-renewable energy source by a renewable energy from the ground vertical loops combined with a heat pump.

The vertical loop of a ground source heat pump system has to be designed using a combination of loop well geometry, loop tube configuration and placement, grout thermal properties, and appropriate ground thermal characteristics, such as conductivity, diffusivity and average ground temperature during the year. The thermal performance of a vertical loop depends on a heat transfer between a borehole heat exchanger and the surrounding soil. The Construction of a heat pump loop includes drilling the vertical borehole into the ground, placement of the loop tube to the bottom of the vertical borehole with the grout tremie and grouting the vertical borehole from the bottom of the vertical borehole to the ground surface (Fig.1). 


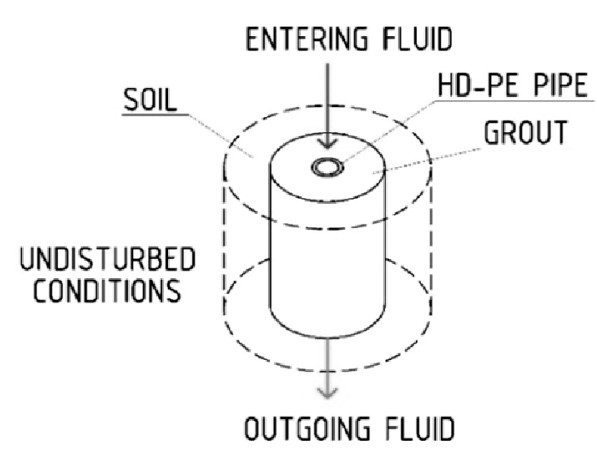

Fig.1. Scheme of the thermal model describing the thermal exchange between the refrigerant fluid and the ground [10]

Ground vertical loops should be designed as long-term sources of heat. The service life of a ground vertical loop should be longer than the service life of a heat pump, which is usually between 20 and 25 years. It should be possible to change a heat pump after its service life and use the existing vertical loop with a new heat pump. To ensure that the loop would work properly for a long period, it is necessary to enable the loop to regenerate. Whether ground temperatures can recover in summer will depend on the region's climate, soil conditions on the spot of the ground loop, and the size of the ground loop. In locations with low ground temperatures and a high annual heating demand, thermal imbalances are of large concern. To make sure, that the loop recovery during summer will be sufficient, it is good to use it as a source of energy for passive or active cooling. A Canadian study confirms that the most common household issues occur with poorly designed systems, which results in the thermal imbalance, where the soil cannot thermally recover.

The brine will be used as a coolant in boreholes. It is a solution of salt in water.

To ensure the efficiently optimal operation of a heat pump and its long service life, the required power input for heating and hot water preparation will be ensured by a cascade of heat pumps. The control system must be designed precisely to reach the optimal operational efficiency. Additional advantages of the heat pump cascade installation:

- At the lowest outside air temperatures the heat pumps will work at the maximum performance level and with the increase in the outside air temperature the heat pump's performance will decrease. In autumn and spring the heat pumps can be gradually disconnected from the system one by one;

- While one heat pump is out of order, there will be another one, which could cover the energy demand at least partly.

The calculations are made for a new highlyinsulated building and for the existing building without modernization in Prague and in St. Petersburg. The housing estate is considered with approximately 500 apartments.

There have been made four variants of calculations:

A - Thermally insulated new building in Prague,

B - Existing building without modernization (1985 and older) in Prague,

C - Thermally insulated new building in St. Petersburg,

D - Existing building without modernization (1985 and older) in St. Petersburg.

The calculation of the annual heating demand is made according to the degree day method, standard [11]. Outdoor temperature is $-12{ }^{\circ} \mathrm{C}$ in Prague and $-26{ }^{\circ} \mathrm{C}$ in St. Petersburg. The average outdoor temperature is $4.3{ }^{\circ} \mathrm{C}$ in first case and $-1.8^{\circ} \mathrm{C}$ in the second. The average indoor temperature is $19^{\circ} \mathrm{C}$ in Prague and $18^{\circ} \mathrm{C}$ in St. Petersburg. The heating season in Prague accounts for 225 days and in St. Petersburg 239. The annual heating demands are summarized in Tab. 3.

Annual heating demands

\begin{tabular}{|l|c|c|c|c|c|}
\hline \multicolumn{2}{|c|}{} & \multicolumn{2}{c|}{ PRAGUE } & \multicolumn{2}{c|}{ SAINT PETERSBURG } \\
\cline { 3 - 6 } \multicolumn{2}{|c|}{} & OPTION A & OPTION B & OPTION C & OPTION D \\
\hline REGUIRED POWER INPUT FOR HEATING & W & 350000 & 1000000 & 475000 & 1500000 \\
\hline DEGREE DAY METHOD & K.day & 33075 & 3307.5 & 4732.2 & 4732.2 \\
\hline ANNUAL HEATING DEMAND & kWh.year $^{-1}$ & 761792 & 2048516 & 1042160 & 2613465 \\
\hline
\end{tabular}


The annual heat demand for hot domestic water preparation is counted for 1000 residents according to the standard [12] for Prague and the standard [13] for St. Petersburg. The temperature of cold water in winter is $5{ }^{\circ} \mathrm{C}$, in summer is $10^{\circ} \mathrm{C}$ and the temperature of hot domestic water is $60{ }^{\circ} \mathrm{C}$. The required amount of hot domestic water is 82 liter.person ${ }^{-1}$. day $^{-1}$ in Prague and 102 liter.person ${ }^{-1} \cdot$ day $^{-1}$ in St. Petersburg. The resulting annual heat demand for hot domestic water preparation is $2563295 \mathrm{kWh} . \mathrm{year}^{-1}$ in the first case and $2381418 \mathrm{kWh} . \mathrm{year}^{-1}$ in the second. The lower energy consumption in St. Petersburg results from the different calculation of heat losses on the circulation piping.

The calculations are made according to the soil parameters from Prague and St. Petersburg. The thermal parameters and dimensions of boreholes are presented in Tab. 4. The soil temperature in non-affected area $\left(t_{z}\right)$ is considered to be $11{ }^{\circ} \mathrm{C}$ in Prague and $10{ }^{\circ} \mathrm{C}$ in St. Petersburg with the change of temperature + $3 \mathrm{~K} / 100 \mathrm{~m}$ depth. The temperatures in boreholes $\left(t_{v}\right)$ are cogitated between -4 to $+4{ }^{\circ} \mathrm{C}$. The specific power of borehole $\left(q_{Z I}\right)$ is calculated by formula 1 . The average value of the specific power of borehole in Prague is $43 \mathrm{~W} \cdot \mathrm{m}^{-1}$, in St. Petersburg 70 W.m ${ }^{-1}$.

$$
q_{z i}=\frac{t_{\mathrm{z}}-t_{\mathrm{v}}}{\left(R_{z}\right)} .
$$

The use of alternative energy sources has limitations. Therefore, it is sometimes more efficient to use one type of the alternative energy supply combined with the conventional methods [14]. The bivalent source of energy is included in the project too. The utilization of heat from ground vertical loops by heat pumps is $70 \%$ and the remaining $30 \%$ is covered by a bivalent source. The bivalent source of energy uses heat from the district heating system. Resulting parameters are summarized in Tab. 5.

To check the temperatures calculated in the depth of boreholes, the actually measured temperature data is used. The temperatures in the sample borehole are measured in CR by the depth in 2013. They are in Fig. 2.

The energy demand for hot domestic water preparation has a preference over the heating demand. In addition, the four-pipe system is used [15]. The scheme of the system is in Fig. 3.

Thermal parameters and dimensions of boreholes

\begin{tabular}{|l|c|c|c|c|}
\hline & sign & Prague & St. Petersburg & units \\
\hline THE THERMAL CONDUCTIVITY OF SOIL & $\lambda_{Z}$ & 1.9 & 3.1 & $\mathrm{~W} \cdot \mathrm{m}^{-1} \cdot \mathrm{K}^{-1}$ \\
\hline DIAMETER OF THE AFFECTED AREA BY BOREHOLE & $D_{Z}$ & 4 & 4 & $\mathrm{~m}$ \\
\hline THE BOREHORE RADIUS & $d_{V}$ & 0.1 & 0.1 & $\mathrm{~m}$ \\
\hline THE PIPE RADIUS & $D N$ & 0.025 & 0.025 & $\mathrm{~m}$ \\
\hline THERMAL RESISTANCE OF BOREHOLE & $R_{Z}$ & 0.309 & 0.189 & $\mathrm{~m} . \mathrm{K}^{\mathrm{W}} \mathrm{W}^{-1}$ \\
\hline
\end{tabular}

Number and depth of boreholes

\begin{tabular}{|l|c|c|c|c|c|c|}
\hline \multicolumn{2}{|c|}{} & \multicolumn{2}{c|}{ Prague } & \multicolumn{2}{c|}{ St. Petersburg } & \multirow{2}{*}{ units } \\
\cline { 3 - 7 } & A & B & C & D & \\
\hline \multirow{2}{*}{ REGUIRED POWER INPUT } & HEAT PUMP & 431.0 & 597.8 & 417.8 & 609.6 & $\mathrm{~kW}$ \\
\cline { 2 - 7 } & BIVALENT & 184.7 & 256.2 & 179.1 & 261.2 & $\mathrm{~kW}$ \\
\hline BOREHOLE LENGTH-TOTAL & $l_{W}$ & 10095 & 14002 & 5997 & 8750 & $\mathrm{~m}$ \\
\hline NUMBER OF BOREHOLES & $p$ & 52 & 72 & 31 & 45 & pieces \\
\hline LENGHT OF 1 BOREHOLE & $l_{\text {each }}$ & 194 & 194 & 193 & 194 & $\mathrm{~m}$ \\
\hline
\end{tabular}




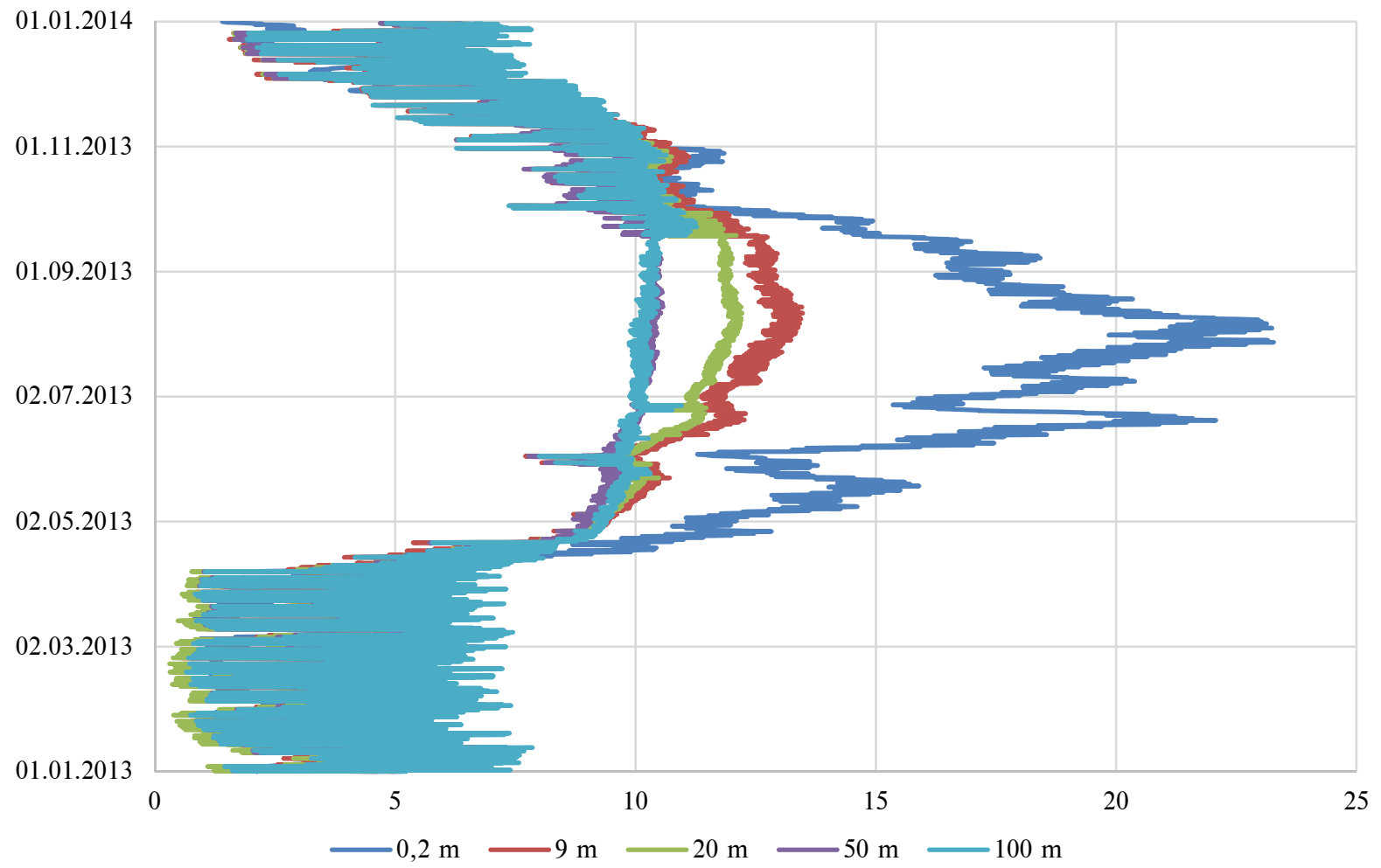

Fig. 2. The temperatures in the sample borehole measured in 2013

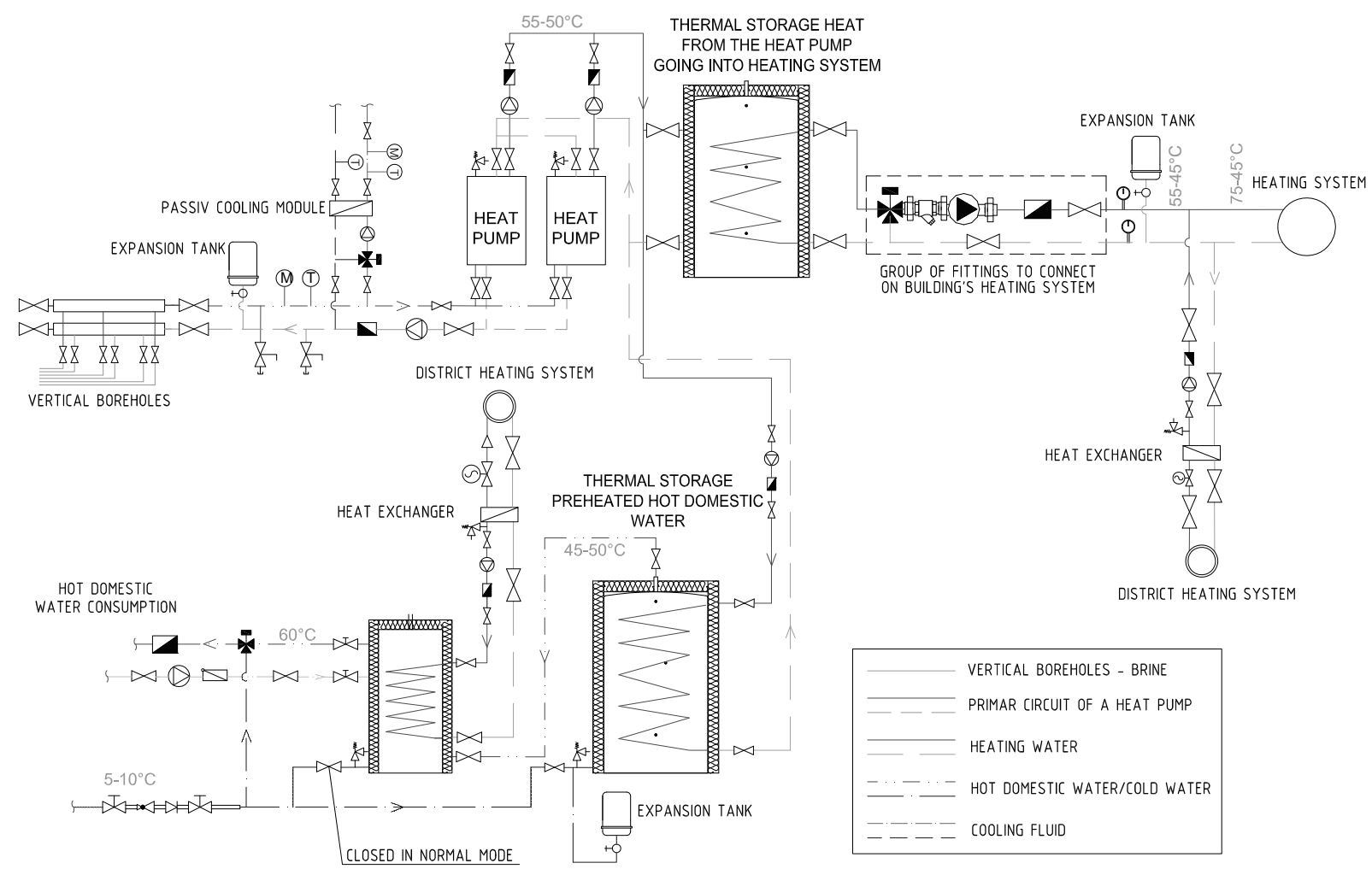

Fig.3. Connection scheme of heating sources 


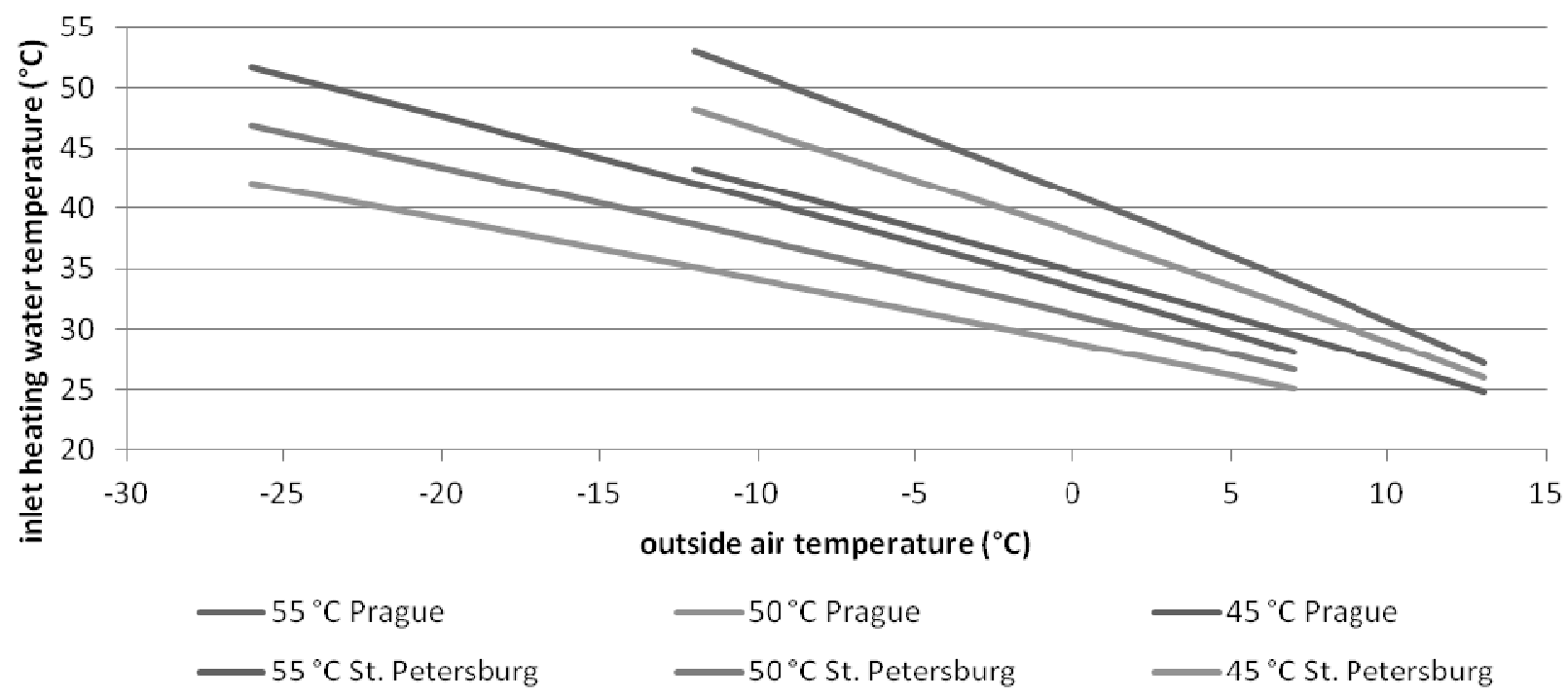

Fig.4. Inlet heating water temperature change according to outside air temperature

There is also a passive cooling module [16]. The main reason for the utilization of passive cooling in the system is to ensure proper regeneration of boreholes. The passive cooling system must be used during summer to cool the indoor air in offices or shops. In summer, the ground is significantly colder at higher depths than the ambient outside air temperature. The heat exchanger installed in the brine circuit transfers the refrigerated capacity to the cooling circuit. The heat pump compressor is not active.

The hot domestic water should be preheated by heat pumps at the temperature of $45{ }^{\circ} \mathrm{C}$ and delivered into hot domestic water storage tanks, placed at the technical room of each apartment building. The water should be heated up by a bivalent source of energy at the temperature of $60{ }^{\circ} \mathrm{C}$.

The temperature of heating water will be controlled according to the outside air temperature. The change of the heating water temperature is presented in Fig. 4. The heating season, as it is seen in the picture, in Prague ends at the outside air temperature of $13{ }^{\circ} \mathrm{C}$ and in St. Petersburg at $8{ }^{\circ} \mathrm{C}$.

The financial comparison has a goal to show the replacement of the district heating energy source in a $100 \%$ range for the ground source heat pump is profitable in the conditions of Prague and St. Petersburg. Two options are compared. The first one is an original district heating system $(100 \%)$ with the traditional source of energy. The second one is a new project with a ground source heat pump (70\%) combined with the bivalent source of energy, heat from the district heating system (30\%). All comparisons are made for options A, B, C, D described above.

The prices are all in Euro. Moreover, all used prices of equipment, materials and salaries are related to the specific conditions of each city.

Costs of the boreholes earthwork, piping and brine coolant are considered in investment costs. In options $\mathrm{A}$ and $\mathrm{C}$, where are new and thermally insulated buildings, three cascade heat pumps are included in investment costs. In options $\mathrm{B}$ and $\mathrm{D}$, where are old buildings without thermal insulation, four cascade heat pumps are included. The cascade control and additional equipment are taken in too. The heat pumps and the related equipment are located at the small utility building with a room for the service man. He has a duty to care about the equipment, control system etc. and he has an eight-hour working day. The investment costs include costs for piping, fittings, circulation pumps, related wiring, cost associated with the project and building permit. Costs of the connection of the station is included too, in a new building (option $\mathrm{A}, \mathrm{C}$ ) it has to be built and in old buildings (option B, D) the station will be reconstructed. There is a $5 \%$ reserve of total investment costs.

The price of heat from the district heating system and price of electricity in original and new systems are calculated in the same way. The price of heat in options A and B (Prague) is from producer «Pražskб teplбrenskб», 2014 [17]. 
The calculated price of heat is 76.6 Euros. $\mathrm{MWh}^{-1}$, the price of electricity is 75 Euro. $\mathrm{MWh}^{-1}$. The price of heat in options C and B (St. Petersburg) is from the data of tariffs in the Kirovsky district in St. Petersburg, 2015. The calculated price of heat is 23.26 Euros. $\mathrm{MWh}^{-1}$, the price of electricity is 36.67 Euros. $\mathrm{MWh}^{-1}$.

The total unit calculated investment costs per MWh of the total energy for the heating and hot domestic water preparation demand per year is 335 Euros. $\mathrm{MWh}^{-1}$ for option A, 318 Euros. $\mathrm{MWh}^{-1}$ for option B, 285 Euros. $\mathrm{MWh}^{-1}$ for option $\mathrm{C}$ and 273 Euros. $\mathrm{MWh}^{-1}$ for option D.

Obviously, a heat pump needs electricity for its drive and its amount is calculated by a bin method [18]. The hourly based data of ground temperatures in a similar sample ground borehole for the heat pump is available and used, (Fig. 2).

The annual saving of operation costs for heating and hot domestic water preparation thanks to a system with a heat pump is calculated as a difference between the price of heat from the current district heating system and the price of heat after the heat pump implementation for all options. The results of the Net Present Value and the Internal Rate of Return are in Tab. 6. The lifetime of heat pumps is calculated as 25 years and the expected return ratio amounts to $3 \%$. The costs of modernization of all the equipment are calculated for 10 years after the installation [19].

Economic results of the project

Table 6

\begin{tabular}{|l|c|c|c|c|c|}
\hline CALCULATED OPTION & - & $\mathrm{A}$ & $\mathrm{B}$ & $\mathrm{C}$ & $\mathrm{D}$ \\
\hline SIMPLE PAYBACK PERIOD & Year & 10.2 & 11.2 & 47.6 & 64.1 \\
\hline NET PRESENT VALUE & Euro & 607762 & 528292 & -704522 & -1107342 \\
\hline INTERNAL RATE OF RETURN & $\%$ & 7.81 & 6.60 & -8.01 & -11.46 \\
\hline
\end{tabular}
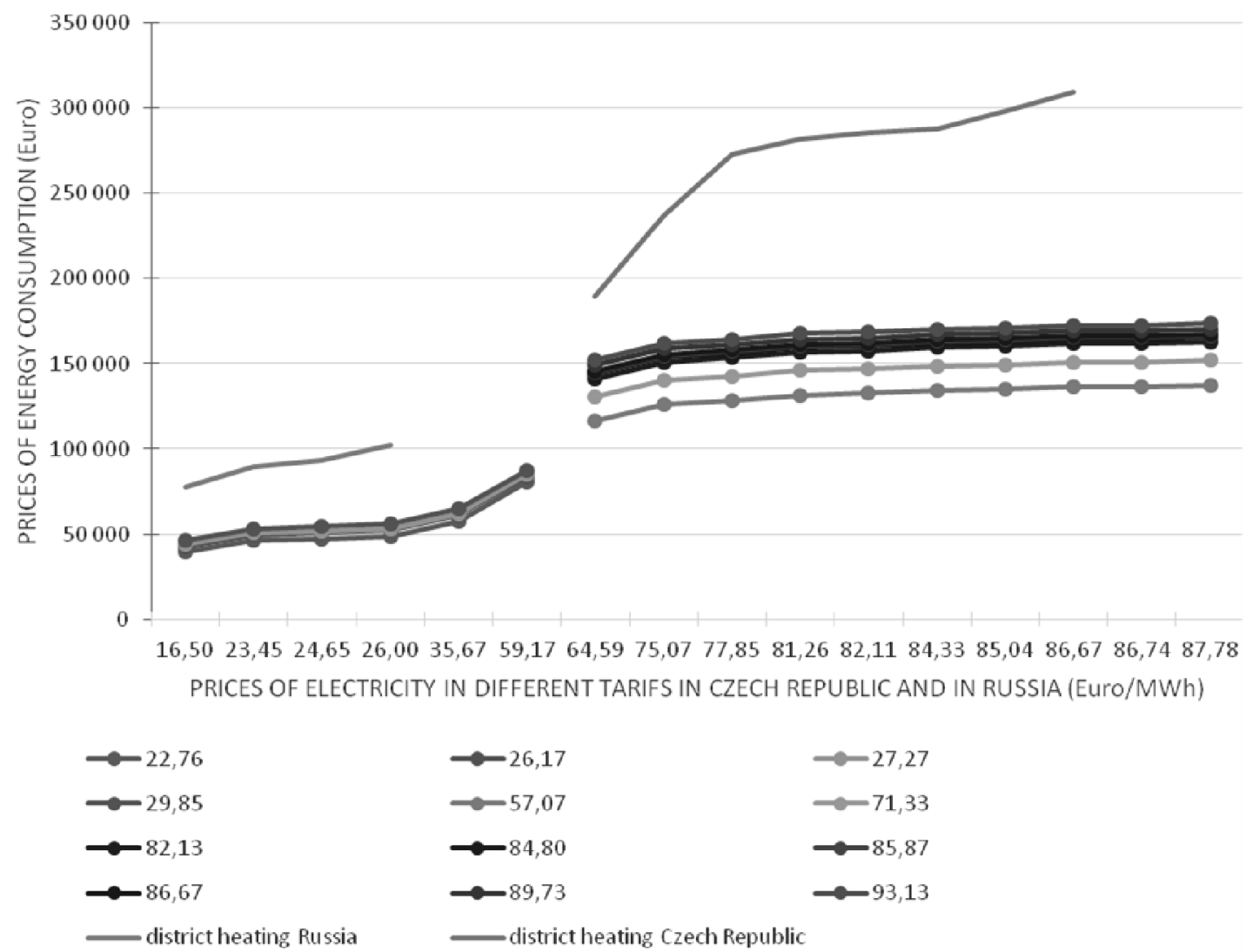

Fig.5. Prices for energy consumption (options A, C) for different tariffs of heat and electric energy 
The economic factors in Tab. 6 show the basic results of installing a heat pump in new or existing buildings in Prague or in St. Petersburg. The installation would be beneficial in Prague in the case of new, thermally insulated buildings and in the case of existing buildings without modernization. The results for St. Petersburg are not favourable. This is due to much lower prices of energies. In St. Petersburg the electric energy is 2 times cheaper and heat energy is 3.3 times cheaper than in Prague.

In the previous evaluation, the prices of energy were used for Prague and St. Petersburg. In the following graph, Fig. 5, prices of the electric energy and heat energy are considered from the district heating systems in RF and CR. Several tariffs are used. On the horizontal axis of the graph, there are prices for electricity in Euros. $\mathrm{MWh}^{-1}$. In the legend under the graph, there are prices of heat energy from the district heating system in Euros.MWh ${ }^{-1}$. The lines with centre marks express prices of the energy consumption for heating and hot domestic water preparation covered mainly by the heat pump (70\%). The smooth lines express prices of energy consumption covered by the district heating system $(100 \%)$.

The graph shows that heating and hot domestic water preparation covered only by the district heating system are more expensive in both CR and RF than the utilization of the system with a heat pump. However, the difference between these two systems is slight in Russia. That is why the project with the combination of a heat pump with the district heating system is not profitable.
To crown it all, there has been made the evaluation for the housing estate with 500 flats in Prague and St. Petersburg for new highly thermal insulated buildings and old traditional building. The four options are calculated. Therefore, a complex comparison of both countries and the evaluation with different tariffs of electric and heat energy have been made too.

The financial comparison shows that the profitability of the evaluated system is different in each country. According to the resulting economic criteria, the profitability of the systems is influenced mainly by prices of heat and electric energy. Investment costs of the heating system with a ground source heat pump do not differ much. According to very low prices of energies in RF, compared with $\mathrm{CR}$, the system with a ground source heat pump is not profitable in Russia.

On the other hand, considering not only economic aspects, the alternative energy sources have different advantages. By reducing the energy dependence on one source of primary energy, it is possible to use the cheaper alternative to the energy source while energy prices are changing. In addition, the impact on the environment is reduced by using renewable energy.

The main result of the subsequent disclosure of the subject is the development of innovative technological solutions for the use of heat pumps in the social sphere in order to improve their economic and thermodynamic appeal.

\section{REFERENCES}

1. Vasilenkov S. Will Russians die from what they breathe? English Pravda RU. URL: http://english.pravda.ru/ russia/economics/30-09-2013/125765-air_pollution_russia-0/ (accused September 30, 2013).

2. Sokolova E.A., Kondratieva E.A., Sergeev V.V., Simonov A.M. Analiz effektivnosti rabotyi teplovyih nasosov v oblastyah srednego i vyisokogo temperaturnyih urovney. Week of science SPbPU: Proceedings of the conference with international participation. The best reports, 2014, pp. 39-44. (rus)

3. Sokolova E.A., Kondratieva E.A., Sergeev V.V., Simonov A.M. Metodika opredeleniya parametrov promyishlennyih teplovyih nasosov sredney teploproizvoditelnosti. Week of science SPbPU: Proceedings of the conference with international participation. Institute of energy and transportation systems, 2014, part II, pp. 145-148. (rus)

4. Danilov O.L. Energosberezheniye v teplotekhnike i teplotekhnologiyakh. M.: MEI, 2010. 188 p.

5. Borovkov, V.M. Al-Alavin, A. Effektivnost primeneniya teplovykh nasosov na teplovykh elektrostantsiyakh s parogazovymi ustanovkami: ucheb. posobiye. $\mathrm{SPb}$.: Izd-vo Politekhn. un-ta, 2008. 263 p. (rus)

6. Orlov M.E. Issledovanie effektivnosti tsentralizovannyih sistem teplosnabzheniya. SKO. Goroda $i$ zdaniya. 2013. T. 7. URL: http://www.journal.esco.co.ua/cities /2013_7/art105.html (rus)

7. URL: http://energostat.cz/teplarenstvi-cr.html

8. URL: http://www.estav.cz/cz/502.teplarny-moder nizuji-rozvody-tepla?hid $=$ cd 793 fa 228

9. Razrabotka innovatsionnyih resheniy po vnedreniyu teplovyih nasosov i ih sovmestnoy ekspluatatsii s teplovyimi elektrostantsiyami na TETs filiala Nevskiy OAO «TGK-1». St. Petersburg, 2013. (rus)

10. Michele De Carli, Stefano Fiorenzato, Angelo Zarrella. Performance of heat pump with direct expansion in vertical ground heat exchangers in heating mode. February 2015, Elsevier.

11. ISO 13 790:2012. (rus)

12. Czech standard SN 060320 (2006) Hot domestic water preparation.

13. SNiP 2.04.01-85. (rus)

14. Sokolova E.A., Amosov N.T. Energosnabzhenie zhilyih i administrativnyih zdaniy $\mathrm{s}$ pomoschyu netraditsionnyih istochnikov energii. XL Week of science $S P b P U$ : Proceedings of the conference with international participation. Part III, pp. 137-139. (rus) 
15. Kukolev M.I., Kukis V.S., Vildjaeva S.N. Generalized assessment method of operating modes of the thermal storage system. Nauchnyie problemyi transporta Sibiri i Dalnego Vostoka: nauchnyiy zhurnal. 2013. № 2. S. 169-172. (rus)

16. Kukis V.S., Kukolev M.I., Vildjaeva S.N. Effektivnost teplovyih nakopiteley energii s odnovremenno protekayuschimi protsessami zaryada i razryada. Vestnik akademii voennyih nauk. 2014. № 4(49). S. 155-162. (rus)
17. URL: http://energostat.cz/ceny-tepla.html

18. EN 15316-4-2 Heating systems in buildings Method for calculation of system energy requirements and system efficiencies, 2008, part 4-2: Space heating generation systems, heat pump systems.

19. Fisenko A.I. Finansovo-jekonomicheskie raschety na predprijatijah i v organizacijah: sbornik zadach i uprazhnenij: ucheb. posobie A.I. Fisenko, 2009. 76 s. (rus)

\section{СПИСОК ЛИТЕРАТУРЫ}

1. Vasilenkov S. Will Russians die from what they breathe? // English Pravda RU. URL: http://english.pravda.ru/ russia/economics/30-09-2013/125765-air_pollution_russia-0/

2.

SOKOLOVA Ekaterina A. - Peter the Great St. Petersburg Polytechnic University.

195251. Politechnicheskaya str. 29. St. Petersburg. Russia. E-mail: sokolenergo@mail.ru

СОКОЛОВА Екатерина Андреевна - ассистент Санкт-Петербургского политехнического университета Петра Великого, PhD.

195251, ул. Политехническая, д. 29, Санкт-Петербург, Россия. E-mail: sokolenergo@mail.ru

LINHARTOVA Vladimir - Czech Technical University in Prague.

16636. Praha 6. Czech Republic. E-mail: vladka.linhartova@email.cz

ЛИНХАРТОВА Владимира - аспирант Чешского технического университета, PhD.

16636, Прага 6, Чешская Республика. E-mail: vladka.linhartova@email.cz

SERGEEV Vitalii V. - Peter the Great St. Petersburg Polytechnic University.

195251. Politechnicheskaya str. 29. St. Petersburg. Russia. E-mail: sergeev_vitaly@mail.ru

СЕРГЕЕВ Виталий Владимирович - зав. кафедрой АиТЭ Санкт-Петербургского политехнического университета Петра Великого, доктор технических наук.

195251, ул. Политехническая, д. 29, Санкт-Петербург, Россия. E-mail: sergeev_vitaly@mail.ru 